\title{
Sub-micrometer waveguide for nano-optics
}

Rottwitt, Karsten; Dyndgaard, Morten Glarborg; Andersen, Karin Nordström; Hansen, T.B.

Published in:

CLEO/Europe

Link to article, DOI:

10.1109/CLEOE.2003.1313762

Publication date:

2003

Document Version

Publisher's PDF, also known as Version of record

Link back to DTU Orbit

Citation (APA):

Rottwitt, K., Dyndgaard, M. G., Andersen, K. N., \& Hansen, T. B. (2003). Sub-micrometer waveguide for nanooptics. In CLEO/Europe (pp. CM3-T). IEEE. https://doi.org/10.1109/CLEOE.2003.1313762

\section{General rights}

Copyright and moral rights for the publications made accessible in the public portal are retained by the authors and/or other copyright owners and it is a condition of accessing publications that users recognise and abide by the legal requirements associated with these rights.

- Users may download and print one copy of any publication from the public portal for the purpose of private study or research.

- You may not further distribute the material or use it for any profit-making activity or commercial gain

- You may freely distribute the URL identifying the publication in the public portal

If you believe that this document breaches copyright please contact us providing details, and we will remove access to the work immediately and investigate your claim 


\title{
Sub-micrometer waveguide for nano-optics.
}

\author{
Karsten Rottwitt, Morten Dyndgaard, and Karin Andersen \\ Research Center COM, Bldg. 345v \\ Technical Univ. of Denmark \\ 2800 Lyngby, Denmark \\ Thorkild B. Hansen \\ Whitten Technologies \\ 295 Huntington Ave. \\ Boston, MA02115, USA
}

Summary: With the recent progress within the field of processing nano structures, such as silicon nano-wires, carbon nano-tubes and silicon crystal waveguides, there is an increasing interest in coupling light into such structures both for characterization of optical properties and new optical components [1]. Examples include measurements on the Raman spectrum of carbon nano-tubes, and an optical switch based on reflection of light against a nano sphere.

In this work we propose the use of a sub-micrometer planar waveguide for probing the reflection of light against a nano structure. The planar waveguide is based on a silicon nitride core layer, surrounded by a silica cladding region. This material system provides a high index difference between the core and cladding region and hence a strong confinement of the electrical field. In our design we utilize this waveuide to couple light into a nano-structure. Recently we have experimentally achieved low propagation loss, $0.7 \mathrm{~dB} / \mathrm{cm}$, in such high index waveguides.

The nano structures that we consider are either carbon nano tubes or silicon nano wires. The diameter of these structures is in the order of tens to hundreds of nanometers. To achieve maximum coupling with the light we have designed a probe as illustrated in Fig 1 . The waveguide is theoretically analyzed using a boundary integral equation method [2]. In this method the mode of the waveguide is assumed to be well known at cross sections far away from the tip $z \rightarrow-\infty$, and the electric field in the tip region is found by applying Green's theorem to the regions around the tip and approaching the boundary from the cladding and core region. With the refractive index profile determined by our material, i.e. $n=1.5$ for the $\mathrm{SiO}_{2}$ cladding and $n=2.1$ for the $\mathrm{SRN}$ cladding, single mode operation is achieved for a cross-section $0.6 \mu \mathrm{m}$ times $0.6 \mu \mathrm{m}$, when the considered wavelength is $1550 \mathrm{~nm}$.

The essential design parameters of the probe are the angle of the tip and the radius of the circle defining the central boundary of the probe see Fig.1. The power reflection coefficient, defined as the power reflected relative to the power launched into the waveguide, is illustrated in Fig. 2 as a function of the design parameters. As opposed to a standard waveguide, based on a germanium doped silica core and a silica cladding region with a refractive index difference of only 0.02 , the preferred tip in the high index waveguide is a long taper, i.e. low taper angle and a small circle radius, $r^{\prime}=25 \mathrm{~nm}$ in Fig. 1. In addition to the optimized design of the waveguide probe we will also report on the reflection versus various reflectors placed in the vicinity of the probe. The reflectors have different size and material properties.

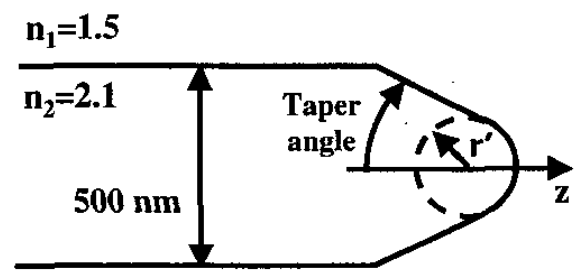

Fig. 1, Definition of geometrical waveguide parameters.

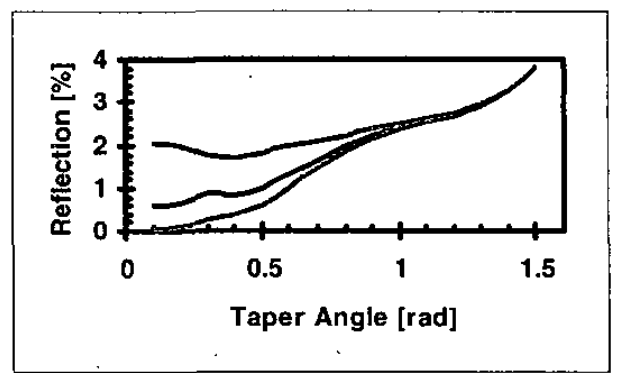

Fig. 2, Reflection versus taper angle for three different circle radii, $r^{\prime}$ in Fig. 1, the upper trace $r^{\prime}=165 \mathrm{~nm}$ the middle trace $r^{\prime}=8 \mathrm{~nm}$ and the lower trace $r^{\prime}=25 \mathrm{~nm}$

Acknowledgements: The Danish Technical Research Council is acknowledged for financial support.

References:

[1] P. Ball, Nature Vol. 409, p. 974 (2001)

[2] M. Tanaka et al., JOSA A, Vol. 15, No. 1, p. 101 (1998) 